Open Access

\title{
Transformation of the company system and birth of the "white-collar" miner: the case of progressive company Taiheiyo Coalmine during the period of economic growth in Japan
}

Naoko Shimazaki®o

Correspondence: nshim@waseda.jp Waseda University, Tokyo, Japan

\begin{abstract}
Following the postwar reconstruction period, Japan enjoyed rapid economic growth from the mid-1950s to the mid-1970s. During those years, Japanese companies, mainly manufacturers, established the Japanese-style production system. However, the coal industry was left behind by the economic growth. One reason for this was the "energy revolution" that occurred in the mid-1950s, namely the replacement of coal with oil as the main energy source. This shift turned coalmining into a declining industry. Coal companies were forced into corporate restructuring, triggering an era of rationalization. Facing this situation, Taiheiyo Coalmine Co. Ltd. took the modernization of its management system further than other mines. As a result, it took up a shift to the Japanese-style production system. This transformation was developed by the joint efforts of labor and management and the company survived through to the twentieth century and still continues to operate today run by the successor to Taiheiyo Coalmine. This paper sets out to elucidate the transformation of the work environment and the change in workers' attitudes in the 1960s and 1970s.
\end{abstract}

Keywords: Rapid economic growth, Coalmining industry, Modernization of management system, Japanese-style production system, Taiheiyo coalmine company, Changes in workers' attitude

\section{Introduction}

Following the postwar reconstruction period, Japan enjoyed rapid economic growth from the mid-1950s to the mid-1970s. During those years, Japanese companies, mainly manufacturers, established the Japanese-style production system. It is common knowledge that a lifestyle embodied by such terms as "a country of 100 million salarymen" and "a 100 million-strong middle class" consequently became prevalent. The coal industry, however, was an exception to this trend. Although the coal industry, together with the steel industry, was key to Japan's postwar reconstruction, it was left behind by the subsequent high economic growth. One reason for this was the "energy revolution" that occurred in the mid-1950s, namely the replacement of coal with oil as the main energy source. This shift turned coalmining into a declining industry. Coal companies were

(c) The Author(s). 2018 Open Access This article is distributed under the terms of the Creative Commons Attribution 4.0 International License (http://creativecommons.org/licenses/by/4.0/), which permits unrestricted use, distribution, and reproduction in any medium, provided you give appropriate credit to the original author(s) and the source, provide a link to the Creative Commons license, and indicate if changes were made. 
forced into corporate restructuring, triggering an era of rationalization. The government intervened with a coal protection policy introduced in 1963. Coal became attractive again at the time of the two oil crises in the 1970s, but Japanese-produced coal was hard hit by price competition from imported coal (Shimazaki 2015). By the time the coal policy ended in late March 2002, all the coalmines in Japan had closed. Today, Kushiro Coalmine Co. Ltd. is the only company producing coal in Japan, using underground mining. Kushiro Coalmine is a descendant of Taiheiyo Coalmine Co. Ltd. discussed in this paper.

The focus is on Taiheiyo Coalmine as the company that took the modernization of its management system further than other mines. In the space of just 10 years, Taiheiyo Coalmine carried out major reforms in five areas - employee status, wages, labor-management relations, housing support and employee welfare - bringing the working lives of mine workers more in line with salaried workers and making their lifestyle more consistent with other Japanese citizens. These changes were underpinned by Taiheiyo Coalmine's mechanization of production in step with other industries. Taiheiyo Coalmine's move took up a shift to the Japanese-style production system that occurred in other industries during the period of high economic growth. This paper sets out to elucidate the transformation of the work environment and the change in workers' attitudes. It also addresses one exceptional case of the white collarization of coal miners, which Koike (1981) referred to as the "birth of white-collar workers" in the Japanese manufacturing industries, concerning their wage system and housing based on the case of Taiheiyo Coalmine.

This analysis calls first of all for an understanding of the features of the personnel management system and wage system in major Japanese mining companies after WW2. The personnel management system had two major features (Shimanishi 2011). First, there was no unified system covering all employees including management positions, technical positions, clerical positions, site foremen and routine workers (both skilled and unskilled miners). Second, there was no explicit definition at the mining workplace of site foremen and routine workers' job descriptions. This meant that the workplace was not organized on the basis of a typical hierarchical structure of working duties (Ichihara 2012; Shimanishi 2013). As a result, the on-site decision-making process was dependent on the age profile of the particular working group. For instance, decisions were often made by older skilled miners rather than a younger site foreman.

In addition, the wage system was dependent on employees' qualifications. A miner's basic wage was made up mainly of a contract-based wage followed by a fixed wage (see Fig. 1). The contract-based wage was merit-based and calculated with respect to the rate of performance for a standard volume of work (Shimanishi 2013), which acted as an incentive for miners. Skilled miners could in effect earn a large merit-based wage, which occasionally far exceeded the site foreman's wage.

After the war, however, Japanese industrial companies other than those working in mining brought in the Japanese-style production system and hence drove up their business growth. This system's central innovation came in the form of changes to the wage and personnel management system. In general, not only in the coal industry but also in the manufacturing industries, until the 1940's there was exact class differentiation system regarding the regular employees. One group was "white-collar" administrative workers, in Japanese called Shokuin, and the other was "blue-collar" manual workers, in Japanese Kôin. The two groups were completely classified separately for all working 


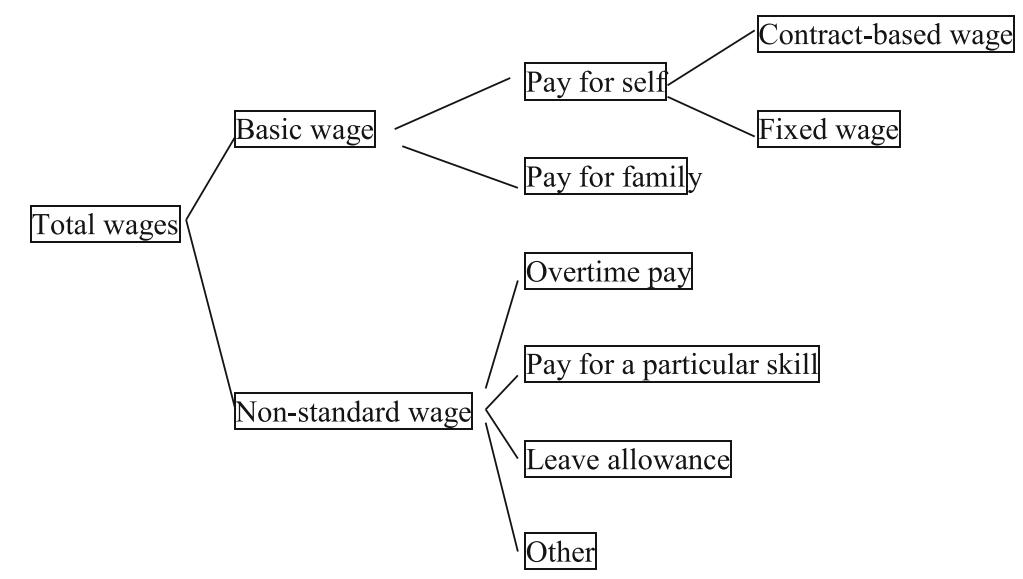

Fig. 1 Wage system in the coal industry: major companies (Shimanishi 2013). *The proportion of contract-based wage to fixed wage is different for every company. *Taken from Sekitan Rôdo Nenkan, 1953

conditions. Abolishing the classification of administrative staff and manual workers had been at the heart of the corporate democratization movement since just after WW2 (Nitta and Hisamoto 2008: 83). Three measures were introduced: abolition of the class system, transformation of the entire personnel management system, including the wage system, and change to the workers' job descriptions in a switch from single-skill workers to cross-trained workers (Shimanishi 2013). The dramatic transformation of Taiheiyo Coalmine in the 1960s, which will be explained below, coincided with the establishment of the Japanese-style production system around the same time.

\section{History of Taiheiyo coalmine and ITS transformation in the 1960s History of Taiheiyo coalmine}

Taiheiyo Coalmine Co. Ltd. mined coal in part of the Kushiro coalfield in eastern Hokkaido. As the company's name suggests ("Taiheiyo" means the "Pacific Ocean" in Japanese), its mine was located in a Pacific seabed area. Taiheiyo Coalmine was founded in 1920 and operated for 82 years until the mine was closed under the government's new coal policy in 2002. After the closure, Kushiro Coalmine Co. Ltd. was established to take over from Taiheiyo Coalmine. Kushiro Coal resumed production at the mine, which still operates today as the only underground coalmine in Japan.

Taiheiyo Coalmine had five notable features, relating mainly to its corporate management. First, its head office was located in Tokyo and it ran only one mine, namely the Kushiro mine. Second, coal produced at the mine was steam coal supplied mainly for use in thermal power generation. Third, coal was extracted from a Pacific seabed coal seam $700 \mathrm{~m}$ under the sea at the deepest point. It was therefore impossible to extract coal through a vertical shaft and mechanization was essential. Fourth, the company's coalmine was an urban-area mine. Coalmining was one of Kushiro City's three major industries along with fishing and paper manufacturing. Kushiro's population reached 227,000 people at its peak in 1980. Fifth, a joint union of administrative staff and mine workers was set up in 1946 and operated through to the mine's closure.

Taiheiyo Coalmine was run in a similar way to the other domestic coalmines through to the 1950s. However, the company introduced some unique measures during the 
period of rationalization in the 1960s. The resulting system formed the foundation for the company's long-lasting survival. In other words, in the period of rationalization, the company achieved a change unusual for the coal industry.

\section{Transformation in the 1960s}

The measures introduced by Taiheiyo in the 1960s dramatically changed key areas of corporate management, such as employee status, wages, labor-management relations, housing support and employee welfare. Although this change was unique to the coal industry, it was in line with the trends observed in Japanese industry in general.

These measures need to be viewed in the light of the premise of the basic business policy of promoting the mechanization of coalmining. Taiheiyo Coalmine's mechanization was inevitable due to the company's shift to undersea mining. While some mechanization was achieved in the prewar period, the mechanization (mining with shield supports and drum cutters) introduced in 1967 ultimately raised the company's mechanization to world-class level (Osanai and Takasaki 2003:56). Consequently, the working method on Taiheiyo Coalmine's coalmining site was different from the methods used by other mines. This will be explained in Section "Revision of the wage system in 1966".

In this paper, I assume that the range of measures introduced in the 1960s started with the merger of two mine mouths into one (new Harutori mine mouth) in 1962. This merger triggered major company-wide organizational reforms, including the unification of personnel management and the establishment of a new business division, resulting in the completion of what Taiheiyo called the "one company, one mine, one mine mouth system." This enabled the implementation of the subsequent measures. Let's look at the five changes in chronological order.

\section{Introduction of the home ownership promotion system in 1962}

In 1962, the home ownership promotion system was introduced. The system was designed to encourage employees to purchase their own homes by developing company-owned land as a residential area for mine workers and selling plots of land to employees. Taiheiyo Coalmine hence shifted from the housing support policy based on company-supplied housing so typical of the coal industry ${ }^{1}$ to a policy based on employee-owned homes. ${ }^{2}$ The company's housing support policy was quite advanced at the time, as most Japanese companies started introducing this system in the 1970s and later (Shinkai, 1997: 223).

Under Taiheiyo Coalmine's home ownership promotion system, employees received a subsidy from the company (a lump sum of 1.65 million) to purchase land and a loan of up to $\backslash 1.8$ million. Employees could also take out loans with public housing loan lenders (Housing Loan Corporation and Employees' Pension Welfare Corporation) and private lenders. Labor organizations such as the labor credit association, Rôdô Kinko, played an important role. Employees on the system received interest subsidies. There were no ageor longevity-related restrictions on the use of the home ownership promotion system. Employees eligible for the system were selected randomly from among applicants with company housing deposits. The home ownership promotion system was designed to: (1) help employees build their assets, (2) ensure stability in retirement, (3) reduce staff turnover, (4) change the staff's outlook by giving them ordinary citizen status, and (5) modernize the mining region (Taiheiyo Coalmine 1980: 82). In order to promote (4) and 
(5), Taiheiyo Coalmine deliberately arranged for mine workers and citizens to live in the same community by opening the company-developed residential area to ordinary citizens. In this way, the company aimed to raise civic awareness among mine workers.

Although employees were initially uneasy about the home ownership promotion system, they came to accept it relatively quickly. Figure 2 shows the annual number of houses constructed for purchase by employees and the cumulative number of houses from 1962 to 1979. It is clear from this figure that home ownership rose sharply from the second half of the 1960s to the first half of the 1970s. By 1979, 17 years after the introduction of the home ownership promotion system, the cumulative number of houses purchased by employees stood at 2452 (Taiheiyo Coalmine 1980). By the time the mine was closed in 2002, $74 \%$ of all employees were living in their own homes. ${ }^{3}$

\section{Abolition of the class system in 1965}

Taiheiyo Coalmine then turned to reforming the employee class system. In 1965, the company announced the abolition of the existing staff class system and, in the following year, it dispensed with the practice of calling administrative staff and mine workers by different names - shokuin (white-collar workers) for administrative staff and kôin (blue-collar workers) for mine workers - and applied the name shain (which could mean either white-collar or blue-collar workers) universally to all employees. As previously explained, this radical change was made in step with the manufacturing industry companies. Taiheiyo Company then introduced a grade system under which employees were divided into professional workers called gijutsushoku-shain (including managers and white-collar workers) and routine workers called sagyôshoku-shain (blue-collar workers). Routine workers were given opportunities to be promoted to professional workers, and powers were devolved from senior to junior positions (Shimanishi 2013: 16).

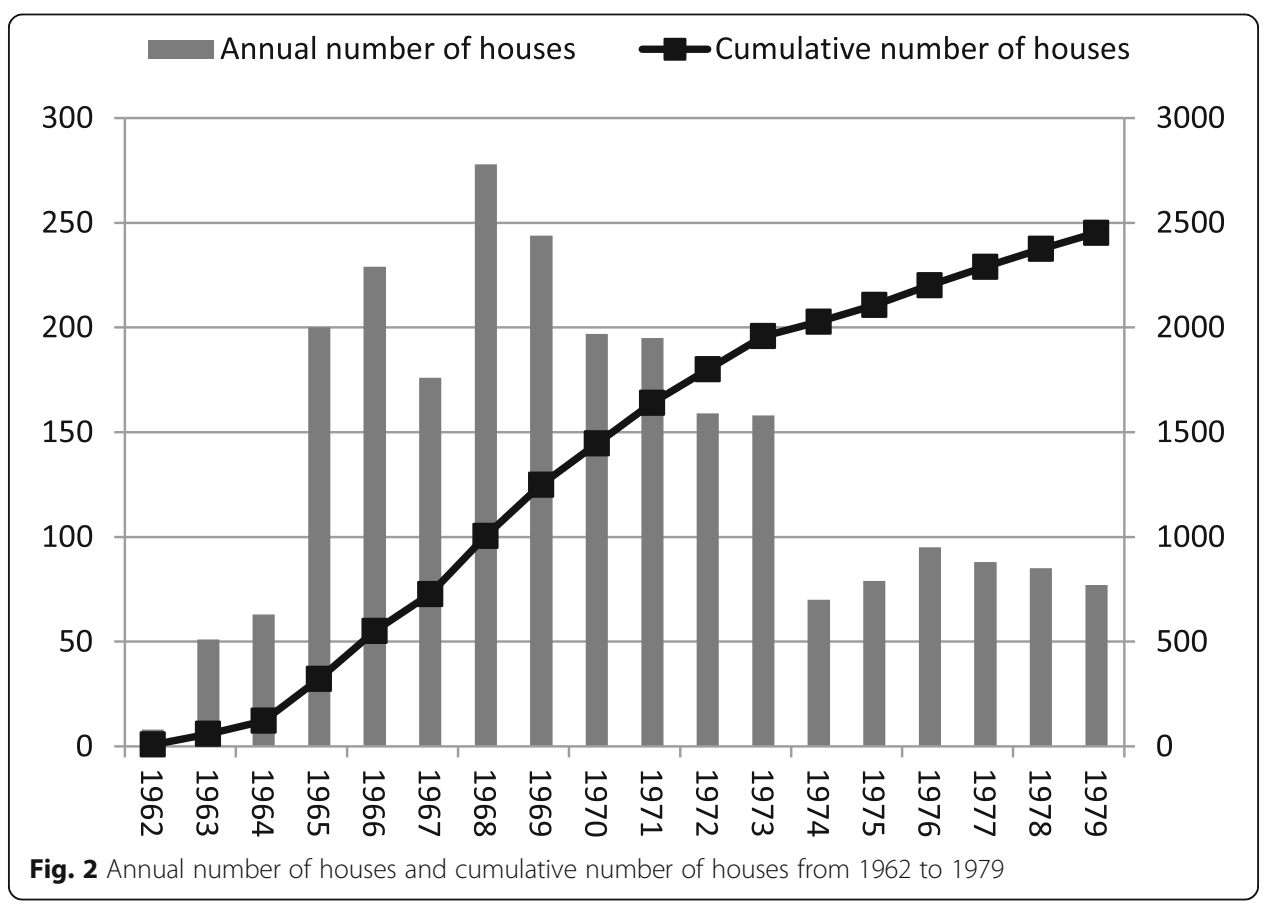


This abolition was only applied to the regular employees. In Taiheiyo, there was another class of non-regular employees, usually called Kumifu, who were contracted workers as in other coal mines.

A senior Taiheiyo Coalmine official explained the company's thinking regarding the abolition of the class system as follows: "In the past, the class system unique to the coalmines may have been necessary as a management framework. But it cannot be denied that this system may nowadays have become a cancer preventing the modernization of feudalistic management. We need to cast off the delusion that keeps us blind to this state of management and views the union itself as being at one with the Communist Party. Once we have recognized this, we should take employee-related measures," (Furutachi 1958: 70). Speaking of the company's situation at the time of the abolition of the class system, a former employee said, "As there were still company-supplied houses for employees, it was not easy to change the system. It took some time. However, the fact that we came to be called shain instead of kôin had a big impact." The employee said that being called shain gave him a sense of pride (Interviews by Shimazaki 2010a, b).

\section{Revision of the wage system in 1966}

Naturally, a class system like this is effectively abolished once inequality of wages and other working terms have been solved. In Taiheiyo Coalmine's case, the wage system was revised. In 1966, the company made a fundamental shift from the contract-based wage system unique to the coal industry, as previously explained, to a fixed wage system. Under the fixed wage system, employees received a fixed wage based on their respective job descriptions. Routine workers' job duties were initially similar to those of single-skill workers. However, following the mechanization introduced in 1967 in the form of SD coalmining (using Shield supports and Drum cutters), routine workers became similar to cross-trained workers. More specifically, in 1969, Taiheiyo Coalmine introduced a worksite system called "broad job category," under which each worker worked a number of jobs (Shimanishi 2013:16-18).

With these changes in the first half of the 1960s, Taiheiyo Coalmine moved closer to the Japanese-style production system established mainly in the manufacturing industry in the 1960s.

Although Taiheiyo also had a safety education program like other mining companies, this program tended to come lower down the agenda as the emphasis was placed on increasing coal production. Later, however, along with the revision of the wage system, Taiheiyo Company extended the reach of employee safety education beyond its management staff. The company introduced training and education programs in which routine workers were willing to participate voluntarily in order to obtain safety certification. The company hence created a safety engineer position in 1973, established an independent safety department in 1976, and built a training center in 1979.

\section{Improvement in labor-management relations in 1967}

Meanwhile, Taiheiyo Coalmine launched a five-year program in 1965 to improve its organizational environment, especially its conflict-ridden labor-management relations. The company used two methods to make the improvement, introduced as American-style management techniques at the time: sensitivity training for individual managers and the managerial grid model developed by R.R. Blake to create an ideal organizational environment. 
These moves were designed to solve the problems that hampered communication and planning, which are the most critical elements of modern management. ${ }^{4}$ More specifically, the company involved the union's leadership in introducing these two methods and conducted a five-stage reform of the organizational environment with the ultimate aim of formulating a long-term plan. ${ }^{5}$

The second stage of the reform was to improve labor-management relations. In this process, labor and management exchanged views about their perceptions of each other and made their respective proposals to improve relations. The proposals were discussed and put into practice following a month of consultations conducted by a management council in 1967. ${ }^{6}$ As a result, labor and management overcame their serious conflicts and successfully switched to new relations based on mutual trust. ${ }^{7}$ These achievements were announced in a joint statement by labor and management stating that, "By taking advantage of these achievements ... the company will renew its resolve to dispel mistrust between labor and management and do its utmost to overcome the coal crisis based on mutual understanding between the two sides." It went on to say that the union would, "seriously consider its own measures to overcome the coal crisis based on its understanding of the company's long-term plan by building on these achievements" (Taiheiyo Coalmine, 1972:42). Labor-management relations hence shifted from conflict to dialogue. Dialogue-based labor-management relations were put into practice in the form of a management council meeting held once a year and regular meetings held by different committees (production committee, wage committee, employee welfare committee and personnel committee). The union thereafter introduced a policy of presenting specific counterproposals in response to proposals from the company and holding consultations on them. In November 1967, a new way of working was defined by such consultations.

It was obviously not an easy task for the union to improve understanding among its members. So it put in place a policy whereby it would discuss any issue that arose with all members. Although this policy necessarily called for a great deal of time to be spent on discussion, the union was determined to maintain union democracy. The process of overcoming conflict within the union will be explained later.

\section{Establishment of an employee welfare cooperative in 1968}

A fundamental employee welfare reform was also conducted. First, the company proposed self-management of employee welfare services. This was a new employee welfare system whose costs would be shared by the company, the staff and society (the local community). Under the system, the company was to provide housing support in the shape of its home ownership promotion system, Kushiro's local government was to improve the living environment and facilities, and staff were to run a mutual society of their own. The aim was to create a modern civil society. In response, the union proposed setting up a welfare cooperative as a self-managed welfare organization to achieve self-management by the workers. ${ }^{8}$ Following consultations, Taiheiyo Welfare Cooperative Taiheiyô Fukushi Kumiai was established in 1968 as the first such organization in Japanese industry. The organization built a welfare hall and a heated pool at a cost of one hundred and seventy million yen. The Taiheiyo Company provided one hundred million yen for this and union members contributed twenty thousand yen each. The members' donations were later returned when the organization folded. In 1969, welfare hall Taiheiyo Sky Land was opened. 
The cooperative's statement of purpose on its establishment noted that, "We have to date been accustomed to company-sponsored benevolent welfare services. However, that has in no way been helpful to us. In the future, we believe that we must make the effort to make the transition to an 'autonomous civil society' and a new welfare service system in step with the times under which union members themselves are responsible for planning and implementation. In order to achieve the 'peaceful, better life' that all of us pray for and aspire to as workers, we will make the effort to create an attractive urban mine by promoting welfare on our own without any intervention by anyone else based on our firm belief that at least Taiheiyo Coalmine will and should survive whatever the situation of coalmining may be."

Taiheiyo Coalmine already had the Taiheiyo Cooperative Taiheiyô Seikatsu Kyôdô Kumiai. Where this was a regional cooperative helping to meet consumption needs, mainly by providing goods, the new welfare cooperative was occupation specific working exclusively on union member welfare activities using common everyday facilities, including the welfare hall. Activities included improving living standards, culture and education, providing allowances for celebratory occasions and mourning, and loans. The welfare cooperative went on to launch a series of new programs, including a comprehensive health examination program for all employees (1972) and a living guidance instructor system (1978). However, the welfare cooperative failed to fill the gap between reality and the ideal, and was disbanded in 1978. Sky Land made a fresh start as a stock company.

The background to Taiheiyo's transformation in the 1960s needs to be explained here. In the face of the decline of the coal industry and the government's coal policy, which encouraged mining companies to close, Taiheiyo Company announced that it was proud of the superiority of mining technology and would refuse the government's subsidies and intervention, and preserve the principle of self-sustaining enterprise and independence as a private company. On the other hand, the union declared that it would agree to Taiheiyo's independence as a private company at that time. However, the union would soon be calling for the nationalization of the coal industry.

As explained above, there was strong disagreement among union members. Distrust of union leaders increased. For instance, there were comments such as, "The company and the union have a cozy relationship," "It looks like a second union," and "we disapprove of the union's policy." Therefore, in 1969, the union reviewed past activities in 1967 and 1968, and declared the new action policy. The policy proposed that the union had to play a central role in changing society and, in order to do this, the union would reaffirm union democracy when debating any issue (Taiheiyo Union, 1986). It has to be clarified that the union's shift from conflict to dialogue did not mean the union became more cooperative with the company. After this transformation, when the company suggested a new policy, the union did not tend to reject it without discussion, but it started to carefully discuss it. After its discussion, the union submitted the alternative proposal concerning the issue, and the company and the union proceeded to the next step of negotiation. It meant the union had an important and active role in mining management.

\section{Birth of "white-collar" mine woRkeRs}

Abolition of the gaikin system in 1970

As explained above, Taiheiyo Coalmine conducted a string of fundamental institutional reforms in less than 10 years, including introducing the home ownership promotion system, 
abolishing the class system, adopting a fixed wage system, developing dialogue-based labor-management relations, and establishing a welfare cooperative. Although, as already mentioned, these reform measures were unusual for the coal industry, what really set the company's change of course apart was the abolition of the gaikin system in 1970. With this reform, Taiheiyo dramatically changed the lives of an entire coalmining community.

In coalmining communities, the gaikin system governing mine workers' lives in both the workplace and the community was a traditionally established system. The system was not just the symbol, but the core of the feudalistic, insular nature of the coalmining communities. In the prewar period and the postwar reconstruction period, it often gave coal companies oppressive control over workers. Under the system, mine workers lived in company-supplied houses near the mine, physically isolated from the outside world. In the segregated residential areas for mine workers, shops, bathhouses, schools and other facilities were built to meet the needs of everyday life in general. Branches of the mine company's labor management division were set up in the area to serve as guidance centers for residents, and labor management personnel were permanently stationed there to over see the mine workers' work attendance and all other aspects of their lives (see Shimazaki 2000).

Taiheiyo Coalmine abolished the gaikin system in September 1970 in an exceptional move for the coal industry. The company closed the residential area branches and stripped back their operations to two facilities, one run by the company and the other by the welfare cooperative.

Taiheiyo Coalmine explained the purpose of abolishing the gaikin system to staff as follows: "Times are changing significantly. Maintaining the traditional labor and personnel management systems indefinitely would be detrimental. Employees should be able to have a free life as citizens at home after finishing work, and that should be a matter for each individual to decide. The main reason for abolishing the guidance centers is to clearly separate out staff's lives as workers at the company from their lives as citizens away from it," (author's emphasis) (Taiheiyô, August 28, 1970). In other words, the abolition of the gaikin system represented a shift from the worker management system controlling workers' lives in both the workplace and the community to a system focused on control in the workplace, leaving workers to lead their lives as ordinary citizens in the community. This is how the work-life balance that is a hallmark of the urban lifestyle came to be.

The abolition of the gaikin system was evidently driven by the reform measures put in place in the 1960s, including the introduction of the home ownership promotion system, the abolition of the class system and the establishment of the welfare cooperative. The company explained that, as a result of these measures, "A modern workforce is being steadily developed, under labor union guidance, with a farsighted vision and a deep understanding of what is at stake, a third of all employees have their own homes, class consciousness has disappeared, and the welfare cooperative's activities have taken hold," (Taiheiyô, August 28, 1970). The union had a similar view in this respect and, regarding the objective to abolish the gaikin system, stressed the need to, "(1) move on from a system that makes all aspects of an individual's life subject to company control based on a feudalistic, insular labor management system that keeps watch over employees' lives; and (2) ensure that employees receive the mental and physical benefits of local autonomy that have been denied them as citizens because of the company's concern for its own interests," (Taiheiyo Coalmine Union, 1966:105). 
An important question arises as to why only the Taiheiyo Coalmine abolished the gaikin system, and why the other mine unions were not eager to dismantle it. There are two reasons for this. First, in 1970, when Taiheiyo abolished the gaikin system, there were only large coalmines operating in Japan, most of which were facing imminent closure. So finding how to keep operations going and deferring closure was a more pressing issue than abolishing the gaikin system.

Another reason was the different way in which Taiheiyo was established and developed its management structures and mining communities. The Taiheiyo Coalmine was built in Kushiro around 1900, when the city had already been developed. Taiheiyo was an inner-city type coalmine, meaning that Taiheiyo's miners were able to keep their coalmining lives separate from their lives as citizens, as previously described in this section. Most other coalfields, however, especially those in large coal company regions such as Yubari, Ashibetsu, and Bibai on Hokkaido, developed differently whereby a coal seam was discovered in the native mountain valley and a coal company subsequently opened a colliery there. This led many miners to move to the area and live in the residential areas that the company set up for them, hence developing a mining community.

In this way, a coalmining company would take control of the region in which the mining community was established and control over all aspects of the miners' lives. For instance, miners could get housing, fuel and electricity, and other benefits as long as they lived in the community. Indeed, miners saw these benefits as an incentive to work in the mining industry. It is not surprising then that dismantling a company's labor management system, i.e. the gaikin system, would not guarantee the improvement or stability of miners' lives.

As described above, by abolishing the gaikin system, Taiheiyo Coalmine's fundamental change of course bore fruit, turning mine workers into "white-collar workers" commuting to work from their own homes and receiving fixed wages.

\section{Change in lifestyle: From mine worker to citizen}

Taiheiyo Coalmine's change of course in the 1960s not only transformed the staff's way of working to bring it more into line with wage earners, but also gave them a lifestyle similar to ordinary citizens. Below, we look at how employees and their families responded to the swift changes to their everyday lives, life plans and work drive.

It goes without saying that the home ownership promotion system had a significant impact. We analyze this based on survey reports compiled by the union and the company. One survey report produced by the union in 1968, six years after the establishment of the system (Taiheiyo Coalmine Union, 1996:82), finds five disadvantages: (1) Some employees had been brought to the brink of personal bankruptcy by the strain on their family finances due to using the system beyond their means; (2) the heavy strain on family finances made it inevitable for employees' wives to work to supplement their husbands' earnings; (3) employees had come to think like the petit bourgeoisie, dissipating the union's fighting capacity; (4) the system put mental pressure on employees living in company-supplied houses; and (5) as it became clear that some employees were unable to use the system, inequality in living standards widened. Among these drawbacks, (4) and (5) have something common with the new inequality that was emerging as a social problem during the period of high economic growth. 
Yet five advantages were also pointed out: (1) Although the system was somewhat compulsory in nature, it promoted forward thinking about life plans; (2) the system raised staff awareness of their low wages; (3) the system improved the staff's ability to view social welfare policy and social security systems with a critical eye; (4) the system increased staff interest in the local community; and (5) employees did not have as great a sense of being tied to company loans as had been expected while they had come to have a sense of stability in their lives. All of these factors point to a gradual staff shift away from total dependence on the company and toward becoming ordinary citizens.

However, a 1978 home ownership report compiled by the company compared mine workers, working underground, and non-mine workers, working outside the pits, divided into homeowners and non-homeowners with respect to four points - work attendance rate, volume of deposits, income level, and payment of life insurance premiums. The report showed that homeowners scored higher than non-homeowners across all four items and concluded that, "Homeowners have a more frugal outlook on life than non-homeowners," (Taiheiyo Coalmine 1978:15). Naturally, the effects of the difference in the age mix between homeowners and non-homeowners need to be discounted. Nonetheless, the benefits of the home ownership promotion system are praiseworthy in view of the high home ownership ratio.

A former employee recalling when he purchased his own home said, "This was a very useful system, and everybody was really happy. Having my own home made me feel very good when leaving my home for work," (interviews by Shimazaki 2010a, 2010b). The wife of another former employee said, "I was worried whether we would be able to make ends meet if we bought a home. So, we first saved money for a home purchase for three years, and it became clear we would be able to manage somehow or other. Therefore, we decided to own a home," (interviews by Shimazaki 2011a, 2011b). Another wife recalled the sense of pride she felt as a citizen when paying utility fees themselves as a result of home ownership. She said, "Previously, all utility fees were paid by the company, but now, we had to pay them ourselves. It was a burden, but we felt relieved to think that it also meant we had become equal to other people in the community and society at large" (interviews by Shimazaki 2011a, 2011b).

On the point of community building, the company's 60th anniversary brochure observed the following in its picture of the community: "The former area of company-supplied houses has changed dramatically, and a community with 5,411 plots of housing with a cheerful, colorful, unique appearance has been created and is buzzing with life as a commuter town for Kushiro City... Its grandeur is remarkable, and with houses competing with each other for their beauty, it is hard to imagine that former mine workers are living here," (Taiheiyo Coalmine 1980:83-84).

\section{Breakdown of the costs of labor management and employee welfare benefits}

Turning now to the impact of these institutional reforms on the management of Taiheiyo Coalmine, we analyze the breakdown of the costs of labor management and employee welfare benefits. In Japanese companies, the cost of employee welfare benefits (excluding cash wages) accounts for a large proportion of total labor costs. This trend is particularly strong in the mining industry. In 1975, cash wages and other allowances accounted for $86 \%$ and $14 \%$ respectively of total labor costs across 
all industries. In the mining industry, the proportion of allowances excluding cash wages was extremely high at $23.2 \%$. This was followed by the utility sectors (electricity, gas, water and heating) at $18.3 \%$, the financial/insurance sector at $15 \%$, and the manufacturing sector at $13.9 \%$. The proportion was low, however, in the service sector $(11.5 \%)$, the real estate sector (12.6\%), and the wholesale/retail sector (12.6\%) with the latter containing a large proportion of small companies (Statistics and Information Department, Ministry of Labor, 1977: Table 1).

The proportion of allowances excluding cash wages was as high as it was in the mining industry due to the high levels of legal welfare costs and retirement allowances. Indeed, cash wages in the mining industry accounted for $\backslash 195,481$ of the total labor costs of $\backslash 254,528$ (average company payment per worker per month), and allowances excluding cash wages accounted for $\backslash 59,047$ (including $\backslash 22,618$ on retirement and other allowances, $\backslash 21,112$ on legal welfare costs, and $\backslash 1814$ on other expenses).

Table 1 Comparison of employee welfare expenses (FY1981) (Yen)

\begin{tabular}{|c|c|c|c|c|}
\hline & Taiheiyo & Coal industry & All industries & Manufacturing \\
\hline \multicolumn{5}{|l|}{ Legal welfare costs } \\
\hline Health insurance & 14,017 & 14,238 & 11,466 & 11,289 \\
\hline Employee pension insurance & 15,892 & 15,917 & 12,336 & 12,398 \\
\hline Employment insurance & 3056 & 3230 & 2998 & 2966 \\
\hline Industrial injury insurance & 23,227 & 32,157 & 2398 & 2097 \\
\hline Coal pension fund & 4981 & 4581 & 35 & 0 \\
\hline Others & 543 & 558 & 434 & 469 \\
\hline Total & 61,716 & 70,681 & 29,667 & 29,219 \\
\hline \multicolumn{5}{|l|}{ Extra-legal welfare costs } \\
\hline \multicolumn{5}{|l|}{ Housing } \\
\hline Family & 17,102 & 13,466 & 3084 & 3188 \\
\hline Single person & 525 & 1809 & 2657 & 3063 \\
\hline Home ownership support & 2635 & 0 & 1875 & 2069 \\
\hline Non-separation & 0 & 0 & 1145 & 974 \\
\hline Subtotal & 20,262 & 15,275 & 8761 & 9294 \\
\hline Medical Insurance & 4192 & 10,618 & 1772 & 2036 \\
\hline \multicolumn{5}{|l|}{ Living assistance } \\
\hline Provision of meals & 0 & 0 & 1880 & 2380 \\
\hline Purchases & 0 & 1321 & 340 & 77 \\
\hline Clothing & 841 & 134 & 489 & 367 \\
\hline Commuting & 2113 & 2367 & 428 & 687 \\
\hline Others & 58 & 527 & 257 & 333 \\
\hline Subtotal & 3012 & 4349 & 3394 & 3844 \\
\hline Celebratory occasions and mourning, insurance & 1472 & 2029 & 1180 & 755 \\
\hline Culture, sports, recreational activities & 1409 & 1180 & 1759 & 1681 \\
\hline Others & 150 & 1704 & 1151 & 1202 \\
\hline Total & 30,497 & 35,155 & 18,017 & 18,812 \\
\hline Grand total & 92,213 & 105,836 & 47,684 & 48,031 \\
\hline
\end{tabular}

Note: Expenses paid by companies per employee per month in 1981 (survey by the Japan Federation of Employers' Association). Reference material prepared by Taiheiyo Coalmine (October 8, 1983) 
Next, let's compare the breakdown of employee welfare costs for Taiheiyo Coalmine, the coal industry, all industries and the manufacturing industry. Table 1 shows the figures for 1981, a year for which relevant data is available. In Taiheiyo Coalmine's case, the amount spent on the home ownership support system as a proportion of extra-legal welfare costs was very high. It was higher than the amount for both the manufacturing industry and the entire coal industry. On the other hand, Taiheiyo Coalmine posted lower medical expenses, living assistance allowances, and allowances for celebratory occasions and mourning than across the coal industry as a whole. This reflects the company's principle of self-management of employee welfare services. Although total employee welfare expenses were higher at Taiheiyo Coalmine and in the coal industry as a whole than across all industries, the breakdown of the company's expenses reflects the reform measures introduced in the 1960s.

\section{Discussion}

As explained in this paper, Taiheiyo introduced major reform measures in the 1960s, including the introduction of the home ownership promotion system, abolition of the class system, adoption of a fixed wage system, development of dialogue-based labor-management relations, establishment of a welfare cooperative, and abolition of the gaikin system, which was the symbol of the coalmining community. With these measures, the company established a Japanese-style production system that was unusual for the coal industry. It changed mine workers' ways of working to bring them more into line with white collar wage earners and gave employees and their families a new lifestyle similar to ordinary citizens. Bear in mind, however, that Taiheiyo's transformation also generated a new kind of inequality. This new inequality was driven by whether miners owned their own home or not, as homeowners received financial assistance from the company. In addition, despite technological advances and industry mechanization, the management style continued to be influenced by the nature of the coal seams and coal accessibility.

Lastly, let's examine the factors and situation at the time that enabled the company to make this change of course. All the reform measures discussed in this paper were launched at the company's initiative. Middle management records kept during the period show that the proposals came from younger proactive managers. This trend came following a boom in business administration studies in the second half of the 1950s. Riding on the "wave of Western business administration studies arriving in Japan in the era of technological innovation" (Furutachi, 1958: 51), younger managers eagerly learned about and applied new methods. The process of improving labor-management relations as discussed in this paper is a good example of that. The younger managers' drive galvanized not only the company's top management, but also the union's leaders.

This tie in with the fact that Taiheiyo Coalmine was not controlled by a zaibatsu group and that the company had a "one company, one mine, one mine mouth system". As of the second half of the 1950s, coalmining went into decline and most coal companies struggled with a business slump (Kikkawa 1996: 200-204). At that time, Taiheiyo Coalmine had no option but to keep its mine in Kushiro in operation if it was to survive. This situation fostered a spirit of ingenuity among younger managers. Furthermore, with mining constraints compelling Taiheiyo Coalmine to mechanize, it became inevitable that it would further consolidate the mining operation at its sole mine and use just one mine mouth. 
However, the loss of alternative options encouraged the union to act on its own initiative. In addition to self-management of employee welfare services, another important initiative not discussed in this paper - self-safety - emerged. Mine safety was imperative for the workers. The development of dialogue-based labor-management relations benefited from the existence of a joint body of administrative staff and mine workers convened by the union since 1946. Many other factors also contributed to the building of mutual trust among employers and mine workers, including the home ownership promotion system, which reduced staff turnover and increased familiarity among employees. All the same, there was clear awareness of the differences between the labor and management standpoints. Conscious efforts were made to avoid growing too close. Long consultations were held on individual issues to discuss the union's counterproposals in order to find a satisfactory conclusion for both sides. At a time when the company and union were trying to transform their relationship, the fact that they both shared the principle of self-sustaining enterprise and the company's independence facilitated the building of mutual trust. There is no doubt that this system was a factor that contributed to Taiheiyo Coalmine's longevity.

However, as explained above, when Taiheiyo introduced major reform measures in the 1960s, there was strong opposition from union members and increased distrust from union leaders. It took a great deal of time to resolve the conflict in the 1970s, following which the union was able to reaffirm union democracy by declaring its new action policy. In Kushiro, the core city on eastern Hokkaido, a coalmine led by modern labor management developed by the joint efforts of labor and management in the period of high economic growth survived through to the twentieth century and still continues to operate today run by the successor to Taiheiyo Coalmine.

\section{Endnotes}

${ }^{1}$ In the mining/coal industry, Houses and other facilities for business purposes need to be built for business management based on location conditions. These houses and facilities, although originally built as production facilities, end up serving as employee welfare facilities. Bathhouses for workers engaged in mining and other manual jobs, and restrooms and boarding facilities for workers in jobs with long nighttime working hours also serve as employee welfare facilities in practice in many cases. However, in terms of social standards, in the light of the nature of the work concerned, the establishment of such facilities should form part of the production facility-related working terms (Kakuta and Ogura 1968:159).

${ }^{2}$ After leaving the mining business, the parent company (Taiheiyô Kôhatsu) provided housing loans.

${ }^{3}$ Ironically, the presence of many homeowners at the time of the mine closure had the effect of curbing the reemployment of mine workers (Shimazaki and Sudo 2013).

${ }^{4}$ Reference is made here to the managerial grid proposed by R. R. Blake, which is a behavioral model that seeks to identify the optimal leadership style based on concern for people and concern for production. A grid seminar is an activity designed to build a corporate team and create an ideal climate for organizational development.

${ }^{5}$ This five-stage improvement was made as follows: first stage (1965 to 1966): introduction; second stage (February to November 1967): improvement in labor-management relations; third stage (March to April 1967: team building trial; fourth stage (June 1967 to 
1968): promotion of team building; and fifth stage (1969 to 1970): attempt to achieve the optimal fourth stage of the grid (long-term plan) (Taiheiyo Coalmine (1972), pp.8-12).

${ }^{6}$ The government called for the establishment of management councils to achieve the objectives of "production management" and "business administration" involving the unions that had emerged amid the intensifying union movement in the postwar era. The establishment of management councils is seen as a crowning achievement of the postwar labor movement (Matsuda (1999), pp. 366-367).

${ }^{7}$ This management council was called Kokoro no Keiei Kyôgikai (heart-to-heart management council), and its history is recorded in detail in a document entitled Kokoro no Keiei Kyôgikai (Taiheiyo Coalmine 1972).

"Self-management of welfare services" was naturally intended to supplement social security, and it goes without saying that the union continued to call for improvements to company-sponsored employee welfare (Taiheiyo Coalmine Union, 1971 and 1977).

9“Welfare News Vol. 2,” Taiheiyo Coalmine Union, July 15, 1968

\section{Acknowledgements}

I would like to thank all those who were interviewed for this research. I would also like to acknowledge the assistance of the Veteran Association of Taiheiyo Coal Mine Administrative Staff. Finally, I would like to offer special thanks to Mr. Takaori Ishikawa, curator of Kushiro City Museum.

Funding

This research was founded by the project entitled "A Coal Mine and the Community during the Last Phase of the Coal Industry: The Life Course of the Final Colliery in Japan" (FY 2012-2014, Principal Investigator: Naoko Shimazaki, Project number: 24530674) funded with a Grant-in-Aid for Scientific Research (C) from the Ministry of Education, Culture, Sports, Science and Technology.

\section{Availability of data and materials}

All of the interviews refer to in this article were conducted in Japanese and transcribed by the author. Some of these materials, with the consent of interviewees, are available in the archives of Kushiro City Library.

\section{Authors' contributions}

This article is the sole work of Prof. NS of Waseda University. The author read and approved the final manuscript.

\section{Author's information}

Sociologist Naoko Shimazaki has been researching and writing about the Japanese coal mining industry for the last twenty years. Her particular focus has been on the re-employment of discharged coal miners, the migration of former miner's families, and the regeneration of former coal mining region and communities. She is Professor of Sociology at Waseda University in Tokyo, Japan.

Competing interests

The author declares that she has no competing interests.

\section{Publisher's Note}

Springer Nature remains neutral with regard to jurisdictional claims in published maps and institutional affiliations.

Received: 29 April 2018 Accepted: 13 July 2018

Published online: 17 August 2018

References

* an asterisk denotes papers in English

Furutachi, R. 1958, Kô no Monban - Keirika no Shokun no Tameni.

Ichihara, H. 2012, "Sengo Tankô Shokuin no Shokumu Kyôiku Shikaku, Jinji Kanri," Sugiyama and Ushijima, Nihon Sekitan Sangyô no Suitai, Keiô Daigaku Shuppankai, 157-190.

Kakuta, Y., and J. Ogura, eds. 1968. Gendai no Shakai Hoshô. Horitsu Bunka Sha.

Kikkawa, T. 1996. Nippon no Kigyô Shûdan - Zaibatsu tono Renzoku to Danzetsu. Tokyo: Yuhikaku Publishing.

Koike, K. 1981. Nihon no Jukuren. Yuhikaku.

Matsuda, M. 1999. Nihon Rômukanri shi: Hokkaidô no Tankô no Jirei wo Chushin ni shite. Tokyo: Chuo Daigaku

Shuppanbu.

Nitta, M., and N. Hisamoto. 2008. Nippon Teki Koyô Sisutemu. Nakanishiya Shuppan.

Osanai, T., and M. Takasaki. 2003. Kaisha Sonbô wa Kake Kaiteika Saikutsu he Chôsen, 49-57. Kushiro Shi.

Shimanishi, T. 2011, Nihon Sekitan Sangyô no Sengoshi, Keiô Gijuku Daigaku Shuppankai. 
Shimanishi, T. 2013 "Taiheiyô Coalmine no Chôki Sonzoku Yôin - Jinji Rômu Kanri Kara no Kôsatsu," JAFCOF Kushiro Kenkyû Kai Research Paper Vol. 2.

Shimazaki, N. (2000, "Daiheizan ni Tomonau Tanko Jûtaku no Saihen - Heizan Chokuzen Kara Shôwa 47 Nen Made - " Masaoka et al (ed.), Tankô Rôdôsha no Heizan Rishoku to Kyaria no Saikeisei Part III, pp. 130-154, Advanced Research Center for Human Sciences, Waseda University, Tokyo.

*Shimazaki, N. 2010a. Community and Workers in the Face of Coal Industry Decline, Paper for the symposium Collective Memories of Coalmining in Japan and Wales held at Waseda University.

Shimazaki, N. 2010b. Community Characteristics and Community Uptake Ability for the Joban Colliery: Consolidation in Preparation for a Comparative Analysis of Coal Producing Areas. Shakai Jôhô 19 (2): 179-195.

*Shimazaki, N. 2011 a. Regeneration in Joban Coalfield: the Role of Local Government. Paper for Comparing Coalfields in Britain and Japan Symposium held at Gregynog North Wales.

*Shimazaki, N. 2011 b. History and Regeneration of Former Coalmining Community, JOBAN in Japan. Paper for CTCC Conference, On the Surface: The Heritage of Mines and Mining held at Innsbruck University.

*Shimazaki, N. 2015. Support for Workers Displaced in the Decline of the Japanese Coal Industry: Formal and Informal Support. Japan Labor Review 112(2): 6-27.

Shimazaki, N., and N. Sudo. 2013. Saigo no Yama: Heizan Rishokusha no Saishûshoku Katei - Taiheiyô Coalmine to Kushiro Chiiki. Annual Report of the Japan Association of Regional and Community Studies 25: 109-125.

Shinkai, Y. 1997, "Kôkyô Seisaku toshiteno Shataku Seido no Bunseki," Fujita and Shionoya, Kigyônai Fukushi to Shakai Hoshô, Tokyo Daigaku Shuppankai, Tokyo, 219-246.

Taiheiyo Coalmine, 1972, Kokoro no Keiei Kyôgikai: Roshi Mondai Kaiketsu e no Michi.

Taiheiyo Coalmine, 1978, Mochiie Hakusho.

Taiheiyo Coalmine, 1980, Rokujunen no Ayumi.

Taiheiyo Coalmine Union, 1986, Taiheiyô Tankô Rôdô Kumiai Yonju nen shi.

Taiheiyo Coalmine Union, 1996, Taiheiyô Tankô Rôdô Kumiai Goju nen shi.

\section{Submit your manuscript to a SpringerOpen ${ }^{\circ}$ journal and benefit from:}

- Convenient online submission

Rigorous peer review

- Open access: articles freely available online

- High visibility within the field

- Retaining the copyright to your article

Submit your next manuscript at $\boldsymbol{\nabla}$ springeropen.com 